\title{
Erwinia aphidicola, a new species isolated from pea aphid, Acyrthosiphon pisum
}

\author{
Hosami Harada, ${ }^{\star, \dagger}$ Hiroshi Oyaizu, ${ }^{1}$ Yoshimasa Kosako, ${ }^{2}$ and Hajime Ishikawa \\ Department of Biological Sciences, Graduate School of Science, ${ }^{1}$ Department of Applied Biological Chemistry, \\ Graduate School of Agriculture and Agricultural Life Sciences, The University of Tokyo, Bunkyo-ku, Tokyo 113, Japan \\ 'Japan Collection of Microorganisms, The Institute of Physical and Chemical Research (Riken), Wako 351-01, Japan
}

(Received October 17, 1997; Accepted December 26, 1997)

\begin{abstract}
Five strains of Gram-negative, oxidase-negative, facultatively anaerobic, fermentative, motile, rodshaped bacterium with the general characteristics of the family Enterobacteriaceae were isolated from the gut of multiple specimens of the pea aphid. All the strains caused aphid mortality when ingested by insects via a synthetic diet. The results of biochemical tests showed that these strains are most related to Erwinia herbicola and Pantoea agglomerans. According to DNA-DNA hybridization, the five strains showed more than $96 \%$ relatedness to each other, indicating that these organisms are members of a single species. These strains were most closely related to Erwinia herbicola (22\% DNA relatedness). Phenotypic differentiation of these strains from Erwinia herbicola, which was also detected from aphid gut, was based on negative reactions in tests of yellow pigment production, gelatin liquefaction, acid production from inulin, starch and dulcitol, and positive acid production from melibiose, inositol, cellobiose and glycerol. On the basis of these data, the name Erwinia aphidicola is proposed for the new organism. The type strain is strain X 001 (=IAM 14479).
\end{abstract}

Key Words__Erwinia aphidicola; insect gut; pea aphid

In a previous study, aerobic bacteria were isolated from aphid gut in order to investigate insect-bacteria interaction, and seven groups were identified as major constituents of the gut flora of the pea aphid, Acyrthosiphon pisum (Harada et al., 1996). Based on the molecular phylogenetic analyses of $16 \mathrm{~S}$ rDNA, three of the seven bacterial groups were identified as members of the family Enterobacteriaceae, and tentatively named bacterium $\mathrm{T}, \mathrm{W}$ and $\mathrm{X}$. DNA-DNA hybridization testing and a phylogenetic tree of $16 \mathrm{~S}$ rDNA indicated that bacterium $\mathrm{T}$ was identical to Erwinia herbicola (Harada et al., 1996).

Bacterium $X$ was detected from almost all the healthy specimens, and was the largest in number among the seven bacterial groups which constituted the major flora of the insect gut (Harada and Ishikawa, 1993; Harada et al., 1996). In enterobacterial groups we examined, only bacterium $\mathrm{X}$, and Er. herbicola successfully infected the gut of the insects that had

\footnotetext{
${ }^{*}$ Address reprint requests to: Dr. Hosami Harada, Department of Biological Sciences, Graduate School of Science, The University of Tokyo, 7-3-1 Hongo, Bunkyo-ku, Tokyo 113, Japan.

${ }^{\dagger}$ Present address: Bio-oriented Technology Research Advancement Institution, Nisshin, Ohmiya 331, Japan.
}

been kept aseptically (Harada and Ishikawa, 1997). Bacterium $X$ grew very well in aphid gut and caused aphid mortality in the laboratory, whereas Er. herbicola seemed to have no effect on insect health.

In this study, the five strains of predominant bacterial species in aphid gut were examined biochemically and by DNA-DNA hybridization. Our results indicated that these bacteria belong to a new species in the genus Erwinia, for which the name Erwinia aphidicola is proposed.

\section{Materials and Methods}

Bacterial strains. Strains X 001, X 081, X 151, X 171 and $X 181$ were isolated from the guts of healthy apterous aphids as previously described (Harada et al., 1996). Whole bodies of the insect, which were surface-sterilized by dipping into $70 \%$ ethanol for $5 \mathrm{~min}$, were washed in sterilized Carlson's solution $(0.7 \%$ $\mathrm{NaCl}(\mathrm{w} / \mathrm{v}), 0.02 \% \mathrm{KCl}(\mathrm{w} / \mathrm{v}), 0.02 \% \mathrm{CaCl}_{2} \cdot 2 \mathrm{H}_{2} \mathrm{O}$ (w/v), $0.01 \% \quad \mathrm{MgCl}_{2} \cdot 6 \mathrm{H}_{2} \mathrm{O}(\mathrm{w} / \mathrm{v}), 0.02 \% \quad \mathrm{NaH}_{2} \mathrm{PO}_{4}$ $(\mathrm{w} / \mathrm{v}), 0.012 \% \mathrm{NaHCO}_{3}(\mathrm{w} / \mathrm{v})$ and $0.8 \%$ glucose $\left.(\mathrm{w} / \mathrm{v})\right)$, and lightly homogenized in the same solution. The homogenate was spread on $\mathrm{L}$ broth agar and incubated overnight at $28^{\circ} \mathrm{C}$ to form colonies of the gut bacteria. 
Table 1. Levels of intraspecies DNA-DNA relatedness of Erwinia aphidicola to selected members of the Enterobacteriaceae.

\begin{tabular}{|c|c|c|c|}
\hline \multicolumn{3}{|c|}{ Source of unlabeled DNA ${ }^{a}$} & \multirow{2}{*}{$\frac{\text { Relative binding ratio }^{b}}{100}$} \\
\hline Erwinia aphidicola & $x$ & $001^{\top}$ & \\
\hline Er. aphidicola & $x$ & 081 & 96 \\
\hline Er. aphidicola & $x$ & 151 & 107 \\
\hline Er. aphidicola & $x$ & 171 & 108 \\
\hline Er. aphidicola & $x$ & 181 & 115 \\
\hline Er. herbicola & JCM & $7000^{\top}$ & 22 \\
\hline Er. ananas & $\mathrm{JCM}$ & $6986^{\top}$ & 20 \\
\hline Er. carotovora & IAM & 12633 & 12 \\
\hline Pantoea agglomerans & JMC & $1236^{\top}$ & 15 \\
\hline Enterobacter asburiae & JCM & $6051^{\top}$ & 15 \\
\hline En. sakazakii & JCM & $1233^{\top}$ & 13 \\
\hline En. intermedius & $\mathrm{JCM}$ & $1238^{\top}$ & 12 \\
\hline En. gergoviae & JCM & $1234^{\top}$ & 6 \\
\hline En. amnigenus & $\mathrm{JCM}$ & $1237^{\top}$ & 13 \\
\hline En. aerogenes & JCM & $1235^{\top}$ & 14 \\
\hline Serratia rubidaea & $\mathrm{JCM}$ & $1240^{\top}$ & 17 \\
\hline S. liquefaciens & $\mathrm{JCM}$ & $1245^{\top}$ & 15 \\
\hline S. ficaria & JCM & $1241^{\top}$ & 18 \\
\hline S. marcescens & JCM & $1239^{\top}$ & 15 \\
\hline Klebsiella pneumoniae & $\mathrm{JCM}$ & $1662^{\top}$ & 10 \\
\hline K. oxytoca & $\mathrm{JCM}$ & $1665^{\top}$ & 10 \\
\hline K. planticola & JCM & $7251^{\top}$ & 14 \\
\hline K. ornithinolytica & JCM & $6096^{\top}$ & 12 \\
\hline
\end{tabular}

a JCM, Japan Collection of Microorganisms; IAM, Institute of Applied Microbiology.

${ }^{b}$ Relative binding ratios were calculated as follows: (fluorescence of heterologous DNA/fluorescence of homologous DNA) $\times 100$. The relative binding ratios are averages from three experiments.

Each of the five strains was established from a distinct individual aphid. These strains were maintained on either a medium containing $1 \%$ Casitone (Difco Laboratories, Detroit, MI, U.S.A.), 0.3\% yeast extract, $0.5 \% \mathrm{NaCl}$ and $0.7 \%$ agar or nutrient agar, and grown at $28^{\circ} \mathrm{C}$. The eighteen reference strains used in this study are listed in Table 1.

Phenotypic characteristics. API 20E strips (bioMerieux-Vitek Japan, Ltd., Tokyo, Japan) were used for preliminary characterizations; API $50 \mathrm{CH}$ strips (bioMerieux-Vitek Japan, Ltd., Tokyo, Japan) were used for fermentation tests. All of these strips were used as directed by the manufacturer. Preparations were incubated at $28^{\circ} \mathrm{C}$ for 2 days, and the results were recorded. Additional tests were performed for citrate and malonate utilization according to standard procedures (Cowan, 1974; Ewing, 1986). Cellular morphology, motility and flagella morphology were determined using cells grown on LB nutrient agar containing $0.5 \%$ yeast extract, $1 \%$ peptone and $0.5 \%$ $\mathrm{NaCl}$.

DNA-DNA hybridization. To prepare the genomic DNA of bacterial strains, cells were grown in nutrient broth at $30^{\circ} \mathrm{C}$ for $24 \mathrm{~h}$ with shaking. DNA was prepared by the method of Marmur (1961). DNA aliquots of strain $\mathrm{X} 001^{\top}$ were labeled with photobiotin, and hybridization studies were done by a method previously described (Ezaki et al., 1989). The fluorescence was read using a fluorometer (CS-9300PC Scanning Densitometer; Shimadzu, Kyoto, Japan).

\section{Results}

\section{Isolation of gut aerobic bacteria from pea aphid}

It was observed that the whole-body extract of surface-sterilized pea aphid contains many groups of bacteria (Harada et al., 1996). To eliminate the contamination by bacteria which adhered to the surface of the aphid body, we performed preparatory experiments. At first, we dipped aphids into a culture of Escherichia coli XL1-blue, which are resistant to tetracycline, and then divided the aphids into 5 groups (each group contained five specimens). Each group of aphids was dipped into $70 \%$ ethanol for $0,2,5,10$ or $15 \mathrm{~min}$, and then washed in sterilized Carlson's solution. Surfacesterilized aphids were homogenized individually in LB liquid medium containing $20 \mu \mathrm{g} / \mathrm{ml}$ tetracycline, and the homogenate was incubated for $24 \mathrm{~h}$ at $30^{\circ} \mathrm{C}$ with shaking. No bacterial growth was detected from any of the aphid homogenates except the control group that had not been treated with $70 \%$ ethanol. Further experiments revealed that treatment with $70 \%$ ethanol for longer than $15 \mathrm{~min}$ eliminates not only the bacteria which adhered to the surface but also those which settled in the gut. For this reason, we employed the treatment with $70 \%$ ethanol for $5 \mathrm{~min}$ to sterilize the surface of the aphids. In addition, it was shown that the extract of digestive tracts surgically isolated from aphids also contains the same kinds of bacteria as those isolated from the whole body, which was confirmed by RFLP analysis of $16 \mathrm{~S}$ rDNA (data not shown). Thus, the bacteria isolated from the wholebody extract of surface-sterilized aphids were supposed to be derived from their digestive tracts. Strains $X 001^{\top}, X 081, X 151, X 171$ and $X 181$ were the predominant group in the aphid gut bacterial flora (Harada et al., 1996).

\section{Phenotypic characterization}

The morphological and biochemical characteristics of the predominant strains in aphid gut are shown in Tables 2 and 3. These strains exhibited the biochemical characteristics of the family Enterobacteriaceae. They were Gram-negative, oxidase-negative, catalase-positive, facultatively anaerobic, fermentative, rod-shaped bacteria which were motile by means of peritrichous flagella. The colonies were ivory, and did not produce the yellow pigment which has been observed in Er. herbicola. The strains grew in nutrient medium from $6^{\circ} \mathrm{C}$ to $40^{\circ} \mathrm{C}$, but not above $42^{\circ} \mathrm{C}$. Opti- 
Table 2. Phenotypic characteristics of Erwinia aphidicola.

\begin{tabular}{|c|c|c|}
\hline Characteristic & $\begin{array}{l}\% \text { of positive } \\
\text { strains }(n=5)\end{array}$ & $\begin{array}{l}\text { Strain } \\
\times 001^{\top}\end{array}$ \\
\hline Pigment production & 0 & $-{ }^{a}$ \\
\hline Motility & 100 & + \\
\hline Growth at $37^{\circ} \mathrm{C}$ & 100 & + \\
\hline Growth at $42^{\circ} \mathrm{C}$ & 0 & - \\
\hline Voges-Proskauer test & 100 & + \\
\hline ONPG ( $\beta$-galactosidase $)^{b}$ & 100 & + \\
\hline Oxidase activity & 0 & - \\
\hline Indole production & 0 & - \\
\hline Nitrate reduction & 100 & + \\
\hline Gelatin liquefaction & 0 & - \\
\hline Tryptophan deaminase activity & 0 & - \\
\hline $\mathrm{H}_{2} \mathrm{~S}$ produced from sodium thiosulfate & 0 & - \\
\hline Arginine dihydrolase activity & 0 & - \\
\hline Lysine decarboxylase activity & 0 & - \\
\hline Ornithine decarboxylase activity & 0 & - \\
\hline Deoxyribonuclease activity & 0 & - \\
\hline Urease activity & 0 & - \\
\hline \multicolumn{3}{|l|}{ Utilization of } \\
\hline Citrate (Simmons) & 100 & + \\
\hline Malonate & 100 & + \\
\hline
\end{tabular}

${ }^{a}+$, positive reaction; - , negative reaction.

${ }^{b} \mathrm{ONPG}, o$-nitrophenyl- $\beta$-D-galactopyranoside.

mal growth was observed between $25^{\circ} \mathrm{C}$ and $35^{\circ} \mathrm{C}$. No growth factors were required since the cells were able to grow in M9 medium.

\section{DNA-DNA hybridization}

The identification probability, which was calculated based on the percent positive of the morphological and biochemical characteristics of the predominant strains in aphid gut, indicated their close relationship to Er. herbicola (Lelliot and Dickey, 1984) and Pantoea agglomerans (Gavini et al., 1989). We further performed DNA-DNA hybridization tests with these species and other phenotypically related species listed in Table 1. It turned out that Er. herbicola (JCM $7000^{\top}$ ) was $22 \%$ related to strain $X 001^{\top}$. The level of relatedness of $P$. agglomerans (JCM $1236^{\top}$ ) was $15 \%$. All the other members of the Enterobacteriaceae tested were less than $20 \%$ related to strain $X 001^{\top}$. Unlabeled DNAs from the four other predominant strains in aphid gut had over $96 \%$ relatedness to strain $\times 001^{\top}$ (Table 1).

\section{Discussion}

The five strains we investigated were shown to be essentially identical phenotypically and highly related to each other as determined by DNA-DNA hybridization, leaving no doubt that they are members of a single species.

All these strains were isolated as the predominant
Table 3. Acid production from various carbohydrates by Erwinia aphidicola.

\begin{tabular}{|c|c|c|}
\hline Acid production from & $\begin{array}{l}\% \text { of positive } \\
\text { strains }(n=5)\end{array}$ & $\begin{array}{l}\text { Strain } \\
\times 001^{\top}\end{array}$ \\
\hline Glycerol & 100 & $+^{a}$ \\
\hline Erythritol & 100 & + \\
\hline D-Arabinose & 0 & - \\
\hline L-Arabinose & 100 & + \\
\hline D-Ribose & 100 & + \\
\hline D-Xylose & 100 & + \\
\hline L-Xylose & 0 & - \\
\hline Adonitol & 100 & W \\
\hline$\beta$-Methyl-D-xyloside & 0 & - \\
\hline D-Galactose & 100 & + \\
\hline D-Glucose & 100 & + \\
\hline D-Fructose & 100 & + \\
\hline D-Mannose & 100 & + \\
\hline L-Sorbose & 0 & - \\
\hline L-Rhamnose & 100 & + \\
\hline Dulcitol & 0 & - \\
\hline Inositol & 100 & + \\
\hline D-Mannitol & 100 & + \\
\hline D-Sorbitol & 40 & W \\
\hline$\alpha$-Methyl-D-mannoside & 0 & - \\
\hline$\alpha$-Methyl-D-glucoside & 0 & - \\
\hline N-Acetyl-D-glucosamine & 100 & + \\
\hline Amygdalin & 100 & + \\
\hline Arbutin & 100 & + \\
\hline Esculin & 100 & + \\
\hline Salicin & 100 & + \\
\hline Cellobiose & 100 & + \\
\hline Maltose & 100 & + \\
\hline Lactose & 20 & - \\
\hline Melibiose & 100 & + \\
\hline Sucrose & 100 & + \\
\hline Trehalose & 100 & + \\
\hline Inulin & 0 & - \\
\hline Melezitose & 0 & - \\
\hline Raffinose & 100 & + \\
\hline Starch & 0 & - \\
\hline Glycogen & 0 & - \\
\hline D-Xylitol & 100 & + \\
\hline$\beta$-Gentiobiose & 100 & + \\
\hline D-Turanose & 0 & - \\
\hline D-Lyxose & 100 & + \\
\hline D-Tagatose & 0 & - \\
\hline D-Fucose & 100 & + \\
\hline L-Fucose & 0 & - \\
\hline D-Arabitol & 0 & - \\
\hline L-Arabitol & 0 & - \\
\hline D-Gluconate & 100 & + \\
\hline 2-Keto-D-gluconate & 100 & + \\
\hline 5-Keto-D-gluconate & 100 & + \\
\hline
\end{tabular}

${ }^{a}+$, positive reaction; - , negative reaction; $W$, weak reaction.

species in aphid gut, and had strong affinity to the aphid gut (Harada et al., 1996; Harada and Ishikawa, 1997b). The results of biochemical tests shown in Tables 2 and 3 suggest that the predominant species in aphid gut is most closely related to Er. herbicola (Lelliot and Dickey, 1984) and P. agglomerans (Gavini et 


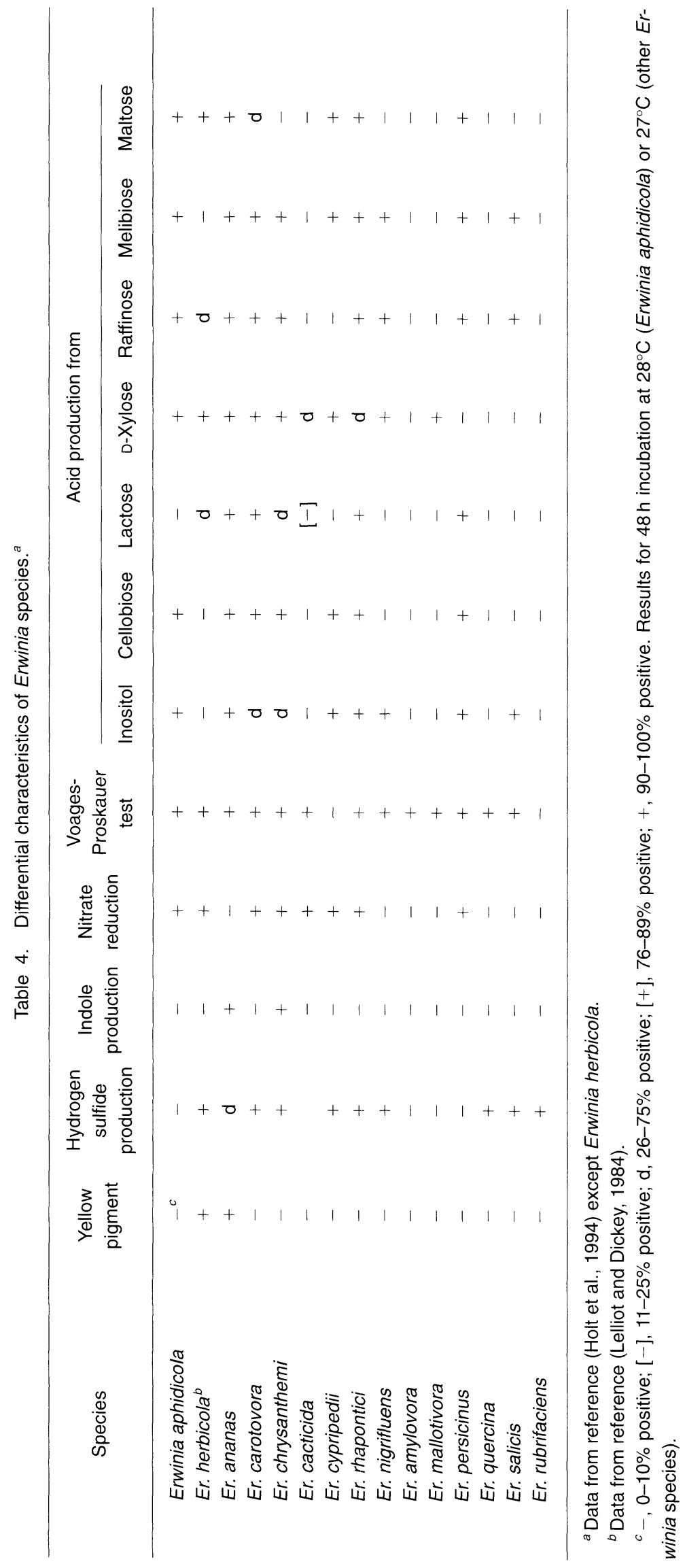


Table 5. Differential characteristics of Erwinia aphidicola and Pantoea species. ${ }^{a}$

\begin{tabular}{|c|c|c|c|c|c|c|c|c|c|}
\hline Characteristic & $\begin{array}{c}\text { Erwinia } \\
\text { aphidicola }\end{array}$ & $\begin{array}{c}\text { Pantoea } \\
\text { ananas }\end{array}$ & $\begin{array}{c}P . \\
\text { stewartii } \\
\text { subsp. } \\
\text { stewartii }\end{array}$ & $\begin{array}{c}P . \\
\text { stewartii } \\
\text { subsp. } \\
\text { indologenes }\end{array}$ & $\begin{array}{c}P . \\
\text { agglomerans }\end{array}$ & $\begin{array}{c}P . \\
\text { dispersa }\end{array}$ & $\begin{array}{c}P . \\
\text { citrea }\end{array}$ & $\begin{array}{c}P . \\
\text { punctata }\end{array}$ & $\begin{array}{c}P . \\
\text { terrea }\end{array}$ \\
\hline Nitrate reduction & $++^{b}$ & $d$ & - & - & + & - & + & + & + \\
\hline Indole production & - & + & - & + & - & - & - & - & - \\
\hline Citrate utilization & + & + & - & + & $d$ & + & + & + & + \\
\hline$\beta$-Galactosidase & + & + & + & + & + & + & + & - & - \\
\hline \multicolumn{10}{|l|}{ Acid production from } \\
\hline glycerol & + & + & - & {$[+]$} & {$[-]$} & $d$ & + & + & + \\
\hline D-arabitol & - & + & - & + & d & + & {$[+]$} & - & - \\
\hline cellobiose & + & + & - & + & $d$ & + & - & - & - \\
\hline maltose & + & + & - & + & + & + & + & {$[-]$} & {$[-]$} \\
\hline lactose & - & + & - & + & {$[-]$} & {$[-]$} & + & - & - \\
\hline$\alpha$-methyl-D-mannoside & - & {$[+]$} & - & - & - & - & - & - & - \\
\hline arbutin & + & + & - & + & + & - & {$[-]$} & - & + \\
\hline salicin & + & + & - & + & + & {$[-]$} & {$[-]$} & - & + \\
\hline raffinose & + & {$[+]$} & + & + & - & - & - & $d$ & d \\
\hline D-turanose & - & - & - & - & - & + & - & - & - \\
\hline D-fucose & + & - & - & - & - & - & + & + & + \\
\hline Hydrolysis of esculin & + & $d$ & - & + & + & + & - & {$[-]$} & + \\
\hline Motility & + & + & - & {$[+]$} & + & + & - & - & + \\
\hline Malonate utilization & + & - & - & - & + & - & - & - & - \\
\hline
\end{tabular}

${ }^{a}$ Data from reference (Mergaert et al., 1993).

$b_{-}, 0-10 \%$ positive; [-], 11-25\% positive; d, 26-75\% positive; [+], 76-89\% positive;,$+ 90-100 \%$ positive. Results are for $48 \mathrm{~h}$ incubation at $28^{\circ} \mathrm{C}$ (Erwinia aphidicola) or $30^{\circ} \mathrm{C}$ (Pantoea species).

Table 6. Differential characteristics of Erwinia aphidicola and phenotypically related members of the family Enterobacteriaceae. ${ }^{a}$

\begin{tabular}{|c|c|c|c|c|c|c|c|}
\hline \multirow{2}{*}{ Species } & \multirow{2}{*}{$\begin{array}{l}\text { Urease } \\
\text { activity }\end{array}$} & \multirow{2}{*}{$\begin{array}{c}\text { Ornithine } \\
\text { decarboxylase } \\
\text { activity }\end{array}$} & \multirow{2}{*}{ Motility } & \multirow{2}{*}{$\begin{array}{c}\text { Gelatin } \\
\text { liquefaction }\end{array}$} & \multirow{2}{*}{$\begin{array}{l}\text { Utilization } \\
\text { of malonate }\end{array}$} & \multicolumn{2}{|c|}{ Acid production from } \\
\hline & & & & & & Inositol & Lactose \\
\hline Erwinia aphidicola & $-{ }^{c}$ & - & + & - & + & + & - \\
\hline Enterobacter asburiae & $d$ & + & - & - & - & - & {$[+]$} \\
\hline En. sakazakii & - & + & + & - & {$[-]$} & {$[+]$} & + \\
\hline En. intermedius & - & + & + & - & + & - & + \\
\hline En. gergoviae & + & + & + & - & + & - & $d$ \\
\hline En. amnigenus & - & + & + & - & + & - & $d$ \\
\hline En. aerogenes & - & + & + & - & + & + & + \\
\hline Serratia rubidaea & - & - & {$[+]$} & + & + & {$[-]$} & + \\
\hline S. liquefaciens & - & + & + & + & - & d & - \\
\hline S. ficaria & - & - & + & + & - & $d$ & {$[-]$} \\
\hline S. marcescens & {$[-]$} & + & + & + & - & {$[+]$} & {$[-]$} \\
\hline $\begin{array}{l}\text { Klebsiella pneumoniae } \\
\text { subsp. pneumoniae }\end{array}$ & + & - & - & - & + & + & + \\
\hline K. oxytoca & + & - & - & - & + & + & + \\
\hline K. planticola & + & - & - & - & + & + & + \\
\hline K. ornithinolytica ${ }^{b}$ & + & + & - & - & + & + & + \\
\hline
\end{tabular}

${ }^{a}$ Data from reference (Holt et al., 1994).

${ }^{b}$ Data from reference (Sakazaki et al., 1989).

${ }^{c}-, 0-10 \%$ positive; [-], 11-25\% positive; d, 26-75\% positive; [+], 76-89\% positive;,$+ 90-100 \%$ positive. Results for $48 \mathrm{~h}$ incubation at $28^{\circ} \mathrm{C}$ (Erwinia aphidicola) or $36^{\circ} \mathrm{C}$ (other species).

al., 1989), which are referred to as synonyms. The result that no species related to the predominant species in aphid gut showed a higher DNA-DNA homology index than $22 \%$ (Table 1), coupled with the differentiation of biochemical characteristics shown in
Tables 4-6, convinced us that the predominant species in aphid gut is different from other members of the family Enterobacteriaceae, and establishes a new species.

From aphid gut, we also detected another group of 
bacterium that produces yellow pigment, which was identified as Er. herbicola based on DNA-DNA hybridization (Harada et al., 1996). Er. herbicola was smaller in number than the predominant species in the aphid gut. Both of the species seem to have adapted to the insect gut environment since they are able to colonize and grow well in the guts of aphid which have been maintained free of microbes (Harada and Ishikawa, 1997b). In addition to this, these species, in common, produced extracellular polysaccharides when they were grown on media which contains sucrose, trehalose or their component monosaccharides (Harada, $\mathrm{H}$., unpubl.). While the DNA relatedness of the predominant species of aphid gut and Er. herbicola indicated in this study was not so high, a close relationship between these species was supported by molecular phylogeny based on the groE nucleotide sequences and its deduced amino acid sequences. The predominant species of aphid gut clearly formed a single cluster with Er. herbicola and Er. ananas (100 and $94 \%$ bootstrap values, respectively) (Harada and Ishikawa, 1997a).

The predominant species in aphid gut is distinguished from the members of the genus Enterobacter by its negative reaction in ornithine decarboxylase, distinguished from members of the genus Serratia by its negative reaction in gelatin liquefaction, and distinguished from members of the genus Klebsiella by its negative reaction in urease (Table 6 ). In considering the phenotypic characteristics, DNA-DNA relatedness and its ecology, the new species should be classified in the genus Erwinia. Below we describe the new species Erwinia aphidicola.

Description of Erwinia aphidicola sp. nov. Erwinia aphidicola (a. phi'di.co.la. L. aphid the aphid; L. suff. -cola dweller; M. L. n. aphidicola, aphid dweller). Cells are Gram-negative, oxidase-negative, catalase-positive, fermentative rods ( 0.5 to 0.6 by 1.6 to $2.0 \mu \mathrm{m}$ ) and motile by means of peritrichous flagella. All strains grow well on nutrient agar and common laboratory media. Colonies on peptone-yeast extract agar are circular and smooth. These organisms grow well at 25,30 and $35^{\circ} \mathrm{C}$, but not at $42^{\circ} \mathrm{C}$. Other biological and nutritional characteristics at $28^{\circ} \mathrm{C}$ are shown in Tables 2 and 3 . The characteristics that differentiate this species from other species are shown in Tables 4-6. The type strain is strain X 001 (=IAM 14479), which was isolated from aphid gut.

This work was supported in part by a research grant from the Program for Promotion of Basic Research Activities for Innovation Biosciences (ProBRAIN) of the Bio-oriented Technology Research Advancement Institution.

\section{References}

Cowan, S. T. (1974) Cowan and Steel's Manual for the Identification of Medical Bacteria, 2nd ed., Cambridge University Press, London.

Ewing, W. H. (1986) Edwards and Ewing's Identification of Enterobacteriaceae, 4th ed., Elsevier, New York.

Ezaki, T., Hashimoto, Y., and Yabuuchi, E. (1989) Fluorometric deoxyribonucleic acid-Deoxyribonucleic acid hybridization in microdilution wells as an alternative to membrane filter hybridization in which radioisotopes are used to determine genetic relatedness among bacterial strains. Int. J. Syst. Bacteriol., 39, 224-229.

Gavini, F., Mergaert, J., Beji, A., Mielcarek, C., Izard, D., Kersters, K., and De Ley, J. (1989) Transfer of Enterobacter agglomerans (Beijerinck 1888) Ewing and Fife 1972 to Pantoea, new genus as Pantoea agglomerans new combination and description of Pantoea dispersa. Int. J. Syst. Bacteriol., 39, 337-345.

Harada, H. and Ishikawa, H. (1993) Gut microbe of aphid closely related to its intracellular symbiont. BioSystems, 31, 185-191.

Harada, H., Oyaizu, H., and Ishikawa, H. (1996) A consideration about the origin of aphid intracellular symbiont in connection with gut bacterial flora. J. Gen. Appl. Microbiol., 42, 17-26.

Harada, H. and Ishikawa, H. (1997a) Phylogenetical relationship based on groE genes among phenotypically related Enterobacter, Pantoea, Klebsiella, Serratia and Erwinia species. J. Gen. Appl. Microbiol., 43, 355-361.

Harada, H. and Ishikawa, H. (1997b) Experimental pathogenicity of Erwinia aphidicola to pea aphid, Acyrthosiphon pisum. J. Gen. Appl. Microbiol., 43, 363-367.

Holt, J. G., Krieg, N. R., Sneath, P. H. A., Staley, J. T., and Williams, S. T. (1994) Bergey's Manual of Determinative Bacteriology, 9th ed., Williams \& Wilkins, Baltimore.

Lelliot, R A. and Dickey, R. S. (1984) Genus VII, Erwinia. In Bergey's Manual of Systematic Bacteriology, Vol. 1., ed. by Krieg, N. R. and Holt, J. G., Williams \& Wilkins, Baltimore, pp. 469-476.

Marmur, J. (1961) A procedure for the isolation of deoxyribonucleic acid from microorganism. J. Mol. Biol., 3, 208-218.

Mergaert, J., Verdonck, L., and Kersters, K. (1993) Transfer of Erwinia ananas (synonym, Erwinia uredovora) and Erwinia stewartii to the genus Pantoea emend. as Pantoea ananas (Serrano 1928) comb. nov. and Pantoea stewartii (Smith 1898) comb. nov., respectively, and description of Pantoea stewartii subsp. indologenes subsp. nov. Int. J. Syst. Bacteriol., 43, 162-173.

Sakazaki, R., Tamura, K., Kosako, Y., and Yoshizaki, E. (1989) Klebsiella ornithinolytica, new species, formerly known as ornithine-positive Klebsiella oxytoca. Curr. Microbiol., 18, 201206. 